\title{
Effect of climate change in Meghalaya as perceived by the scientists of Krishi Vigyan Kendra, Meghalaya, India
}

\section{Guneshori Maisnam*, Deimayami Nongtdu and Lewotki Rangad}

Department of Agricultural Extension, Bidhan chandra Krishi Viswavidyalaya, Nadia-741252 (West Bengal), INDIA

*Corresponding author. E-mail: gunemaisnam@gmail.com

Received: April 17, 2015; Revised received: October 3, 2015; Accepted: January 30, 2016

\begin{abstract}
A study was conducted to assess the adverse effect of climate change as perceived by the scientists of Krishi Vigyan Kendra,Megahlaya. Data were collected from 25 scientists by questionnaire method in the month of October,2012 to January,2013. For this purpose five important components viz. Environment, Hill agriculture and allied, Human and animal health, Forest and wildlife and Hydrology and water resources were identified and presented to the scientists in pairs, in 10 possible combinations, and the scientists were requested to select one component from each pair separately which would be more adversely affected, than the other component due to climate change. For analysis of data the method of Paired Comparisons was followed.It was found that due to climate change Hill agriculture and allied may be severely damaged with highest scale value of 1.513 followed by hydrology and water resources(0.629),environment(0.418),forest and wildlife(0.029) and least affected component is Human and animal health(0.00). The findings revealed that Hill agriculture will be most adversely affected due to climate change in Meghalaya.One of the main reason is practising of jhum cultivation. Therefore,the scientists and the government of Meghalaya may adopt some necessary steps for controlling jhum cultivation
\end{abstract}

Keywords: Climate change, Krishi Vigyan Kendra, Paired comparisons

\section{INTRODUCTION}

Climate change has been recognized as the foremost environmental problem of the $21^{\text {st }}$ century and has become a subject of considerable debate. It is predicted to lead to adverse, irreversible impact on earth and the ecosystem as a whole (Sasmita and Mohanty, 2009).Climate change will directly affect the agricultural production, water resources, natural ecosystem, biodiversity, animal and human health. The Indian Network for Climate Change Assesment (INCCA) report warns of impact such as sea level rise, increase in cyclonic intensity, reduced crop yield in rainfed crops, stress on livestock, reduction in milk productivity, increases flooding and spread of malaria (Mondal, 2013).

The North Eastern Region of India is expected to be highly prone to the consequences of climate change because of its geo-ecological fragility, strategic location vis-à-vis the eastern Himalayan landscape and international borders, its trans-boundary river basins and its inherent socio-economic instabilities. Environmental security and sustainability of the region are and will be greatly challenged by these impacts. The region falls under high rainfall zone with subtropical type of climate. Droughts and floods are the adverse climatic conditions arising out of deficit and excess rainfall, respectively. Drought assumes significance mainly in rainfed conditions like in North East India. Unprece- dented drought like situation affected very adversely the whole North East Region in recent years. Floods are equally devastating in the region. The increasing melting of glaciers in Himalayas is of great concern for the region (Deepika and Pasricha, 2010).

Based on the recommendation of the Education Commission (1964-66), consideration / review by the Planning Commission and Inter-Ministerial Committee, and further recommendation by the committee headed by Dr.Mohan Singh Mehta appointed by ICAR in 1973 the idea of establishment of Farm Science Centre (Krishi Vigyan Kendra) was evolved. The first Krishi vigyan kendra (KVK), on a pilot basis, was established in 1974 at Pondicherry under the administrative control of the Tamil Nadu Agricultural University, Coimbatore, in 1976-77.

At present there are five KVKs in five different districts of Meghalaya and these are: KVK Jaintia Hills, KVK East Khasi Hills, KVK West Khasi Hills, KVK Ri Bhoi and West Garo Hills. A total of 29 scientists of different disciplines are working in this KVKs. The present study was conducted to assess the effect of climate change as perceived by scientists of KVK in Meghalaya.

\section{MATERIALS AND METHODS}

Sampling design: The present study was conducted on 
Table 1. Sampling method.

\begin{tabular}{lll}
\hline Districts & $\begin{array}{l}\text { Number } \\
\text { of KVK } \\
\text { scientists }\end{array}$ & Sampling Method \\
\hline Jaintia Hills & 5 & Total enumeration \\
East Khasi Hills & 5 & Total enumeration \\
West Khasi Hills & 5 & Total enumeration \\
West Garo Hills & 5 out of 7 & Random sampling \\
Ri Bhoi & 5 out of 7 & Random sampling \\
TOTAL & 25 & \\
\hline
\end{tabular}

the scientists of $5 \mathrm{KVK}$ located in 5 districts of Meghalaya to assess their perception on impact of climate change. Data were collected from 25 scientists by questionnaire method. The questionnaire were distributed to the scientists in the month of October 2012 and the filled in questionnaire were collected in the month of January, 2013.

Projected impact of climate as perceived by the scientists of KVK : The projected impact of climate change is likely to affect environment, agriculture and allied sectors, forest and wild life, hydrology and water resources, etc in the North East India. These five important components were identified and presented to the scientists in pairs, in 10 possible combinations. The sub-components of these five components are presented below.

Environment: Sub components were: 1.Increase of temperature 2.Emission of green house gas 3.Landslide 4.Drought 5.Natural disaster like occurrence off flood, drought, storm, cold waves etc. 6. Cyclone and super cyclone 7.Hail stone 8 . Change of biodiversity
10.Change of monsoon

Hill agriculture and allied: Sub components were: 1.Production and productivity of field crop 2. Horticulture crops 3. Cropping pattern 4. Farming system 5. Food security 6. Inland fisheries 7. Cost of cultivation 8. Animal production 9. Dairy production etc.

Human and animal health: Sub components were: 1.Spread of water borne and airborne diseases 2. More outbreaks of deadly diseases 3. Breeding space for different insect vectors and pathogen

Forest and wildlife: Sub components were: 1.Deforestation 2. Occurrence of massive forest fire 3 . Migratory birds 4. Survival of wild life

Hydrology and water resources: Sub components were: 1.Availability of ground water for irrigation 2 . Water for domestic and industrial purpose.

Climate change can adversely affect all these components and sub components more or less. To assess the effect of climate change as perceived by the scientists of KVK, the method of Paired Comparisons (Edwards, 1969) was adopted. For this purpose the five components were presented to the scientists of $\mathrm{KVK}$ in pairs, in 10 possible combinations. The scientists were requested to select one component from each pair which they consider will be more adversely affected than the other due to climate change. The ten pairs are presented below:
(A) Environment
(A) Environment
(B) Hill Agriculture and allied (C) Human and Animal health
(A) Environment
(A) Environment
(D) Forest and Wildlife
(E) Hydrology and water resources

Table 2. F-matrix of 5 components relating to climate change judged by 25 respondents (scientists of KVK).

\begin{tabular}{|c|c|c|c|c|c|}
\hline Components & $\begin{array}{l}\text { Environment } \\
\text { (A) }\end{array}$ & $\begin{array}{l}\text { Hill agriculture } \\
\text { and allied }(B)\end{array}$ & $\begin{array}{l}\text { Human and } \\
\text { animal health(C) }\end{array}$ & $\begin{array}{l}\text { Forest and } \\
\text { wildlife (D) }\end{array}$ & $\begin{array}{l}\text { Hydrology and } \\
\text { Water resources(E) }\end{array}$ \\
\hline Environment & - & 20 & 10 & 11 & 11 \\
\hline $\begin{array}{l}\text { Hill agriculture } \\
\text { and allied }\end{array}$ & 5 & - & 6 & 1 & 5 \\
\hline $\begin{array}{l}\text { Human and ani- } \\
\text { mal health }\end{array}$ & $15 *$ & 24 & - & 20 & 18 \\
\hline $\begin{array}{l}\text { Forest and wild- } \\
\text { life }\end{array}$ & 14 & 24 & 5 & - & 22 \\
\hline $\begin{array}{l}\text { Hydrology and } \\
\text { Water resources }\end{array}$ & 14 & 20 & 7 & 3 & - \\
\hline
\end{tabular}

*To be understood as 15 scientists preferred Environment to Human and animal health i.e. Environment will be more affected than Human and animal health and so on.

Table 3. P-matrix corresponding to the F-matrix.

\begin{tabular}{|c|c|c|c|c|c|}
\hline Components & $\begin{array}{l}\text { Environment } \\
\text { (A) }\end{array}$ & $\begin{array}{l}\text { Hill agriculture } \\
\text { and allied }(\mathrm{B})\end{array}$ & $\begin{array}{l}\text { Human and } \\
\text { animal health }(C)\end{array}$ & $\begin{array}{l}\text { Forest and } \\
\text { wildlife (D) }\end{array}$ & $\begin{array}{l}\text { Hydrology and } \\
\text { Water resources(E) }\end{array}$ \\
\hline Environment & 0.500 & 0.800 & 0.400 & 0.440 & 0.440 \\
\hline $\begin{array}{l}\text { Hill agriculture and } \\
\text { allied }\end{array}$ & 0.200 & 0.500 & 0.240 & 0.040 & 0.200 \\
\hline $\begin{array}{l}\text { Human and animal } \\
\text { health }\end{array}$ & 0.600 & 0.960 & 0.500 & 0.800 & 0.720 \\
\hline Forest and wildlife & 0.560 & 0.960 & 0.200 & 0.500 & 0.880 \\
\hline $\begin{array}{l}\text { Hydrology and Water } \\
\text { resources }\end{array}$ & 0.560 & 0.800 & 0.280 & 0.120 & 0.500 \\
\hline SUMS & 2.420 & 4.020 & 1.620 & 1.900 & 2.740 \\
\hline
\end{tabular}


Table 4. Re-arranged P -matrix.

\begin{tabular}{|c|c|c|c|c|c|}
\hline Components & $\begin{array}{l}\text { Human and Ani- } \\
\text { mal Health (C) }\end{array}$ & $\begin{array}{l}\text { Forest and } \\
\text { Wildlife (D) }\end{array}$ & $\begin{array}{l}\text { Environ- } \\
\text { ment (A) }\end{array}$ & $\begin{array}{l}\text { Hydrology and Water } \\
\text { Resources (E) }\end{array}$ & $\begin{array}{l}\text { Hill agriculture } \\
\text { and allied }(B)\end{array}$ \\
\hline $\begin{array}{l}\text { Human and Animal } \\
\text { Health }(C)\end{array}$ & 0.500 & 0.800 & 0.600 & 0.720 & 0.960 \\
\hline $\begin{array}{l}\text { Forest and Wildlife } \\
\text { (D) }\end{array}$ & 0.200 & 0.500 & 0.560 & 0.880 & 0.960 \\
\hline Environment (A) & 0.400 & 0.440 & 0.500 & 0.440 & 0.800 \\
\hline $\begin{array}{l}\text { Hydrology and Water } \\
\text { Resources (E) }\end{array}$ & 0.280 & 0.120 & 0.560 & 0.500 & 0.800 \\
\hline $\begin{array}{l}\text { Hill agriculture and } \\
\text { allied (B) }\end{array}$ & 0.240 & 0.040 & 0.200 & 0.200 & 0.500 \\
\hline SUMS Z & 1.620 & 1.900 & 2.420 & 2.740 & 4.020 \\
\hline Components & $\begin{array}{l}\text { Human and } \\
\text { Animal } \\
\text { Health }(\mathrm{C}) \\
\end{array}$ & $\begin{array}{l}\text { Forest and } \\
\text { Wildlife (D) }\end{array}$ & $\begin{array}{l}\text { Environment } \\
\text { (A) }\end{array}$ & $\begin{array}{l}\text { Hydrology and } \\
\text { Water Re- } \\
\text { sources (E) }\end{array}$ & $\begin{array}{l}\text { Hill agriculture } \\
\text { and allied (B) }\end{array}$ \\
\hline $\begin{array}{l}\text { Human and Animal } \\
\text { Health (C) }\end{array}$ & 0.00 & 0.842 & 0.253 & 0.583 & 1.751 \\
\hline Forest and Wildlife (D) & -0.842 & 0.000 & 0.151 & 1.175 & 1.751 \\
\hline Environment (A) & -0.253 & -0.151 & 0.000 & -0.151 & 0.842 \\
\hline $\begin{array}{l}\text { Hydrology and Water } \\
\text { Resources (E) }\end{array}$ & -0.583 & -1.175 & 0.151 & 0.000 & 0.842 \\
\hline $\begin{array}{l}\text { Hill agriculture and allied } \\
\text { (B) }\end{array}$ & -0.706 & -1.751 & -0.842 & -0.842 & 0.000 \\
\hline SUMS Z & -2.384 & -2.235 & -0.292 & 0.765 & 5.186 \\
\hline MEAN Z & -0.476 & -0.447 & -0.058 & 0.153 & 1.037 \\
\hline $\begin{array}{l}\text { (Add largest negative } \\
\text { deviation) }\end{array}$ & 0.476 & 0.476 & 0.476 & 0.476 & 0.476 \\
\hline RANK (scale value) R & $\begin{array}{l}0.000 \\
5^{\text {th }}\end{array}$ & $\begin{array}{l}0.029 \\
4^{\text {th }}\end{array}$ & $\begin{array}{l}0.418 \\
3^{\text {rd }}\end{array}$ & $\begin{array}{l}0.629 \\
2^{\text {nd }} \\
\end{array}$ & $\begin{array}{l}1.513 \\
1^{\text {st }}\end{array}$ \\
\hline
\end{tabular}

(B) Hill Agriculture and allied (B) Hill Agriculture and allied

(C) Human and animal health (D) Forest and Wildlife

(B) Hill Agriculture and allied (C) Human and Animal health

(E) Hydrology and water resources (D) Forest and wildlife

$\begin{array}{ll}\text { (C) Human and Animal health } & \text { (D) Forest and wildlife }\end{array}$

(E) Hydrology and water resources (E) Hydrology and Water resources

Method of paired comparisons: Thurstone developed the law of comparative judgement which provides rationale for the ordering of stimuli along a psychological continuum. It is a psychological scaling method and makes possible the quantitative investigation of all kinds of values and subjective experiences (Edwards,1969). In this method, the stimuli (items, statement or variables) are presented in pairs in all possible combinations and the respondents are asked to select one stimulus over the other from each pair, which is judge as more favourable. This is known as Method of Paired Comparisons. This method also provides an estimate of the distances between each of the stimuli, in comparison to the stimulus with least preference, whose scale value is (arbitrarily) brought down to the level of 'zero'. If there are n stimuli, the number of pairs which may be obtained are $n(n-1) / 2$.

\section{RESULTS AND DISCUSSION}

The climate change will adversely affect all the components in North East as perceived by the scientists of
KVK of Meghalaya. Table 2. shows the frequencies corresponding to the number of times that each stimulus is judged more favourable than the other.Table-3. gives the proportion of times the column stimulus is judged more favourable than the row stimulus. Table 4.shows the stimulus having the smallest column at the left and that with the highest at the right. From Table4.(Z-matrix) it was found that Hill Agriculture and Allied (B) will be affected most severely due to climate change and it has been ranked $1^{\text {st }}$ (highest scale value 1.513) among the five components. The main reason is most of the Hill agriculture are rainfed in nature and majority of the farmers in North East Region and Meghalaya in particular practise jhum cultivation which is very much dependent on climatic factors (Ramakrishnan,1990)

The next component which will be affected most by climate change is Hydrology and water Resource (E) having scale value of $(0.629)$ and ranked $2^{\text {nd }}$. Even though Meghalaya is well known for being the wettest place on earth it still faces problem of water scarcity and drought. Since most of the farmers in Meghalaya still practise jhum cultivation which is totally dependent on rainfall therefore hydrology and water resources play a very important role. Loss of mountain snowpack reduces the amount of water available for irrigation downstream, while earlier spring snowmelt affects the timing. 


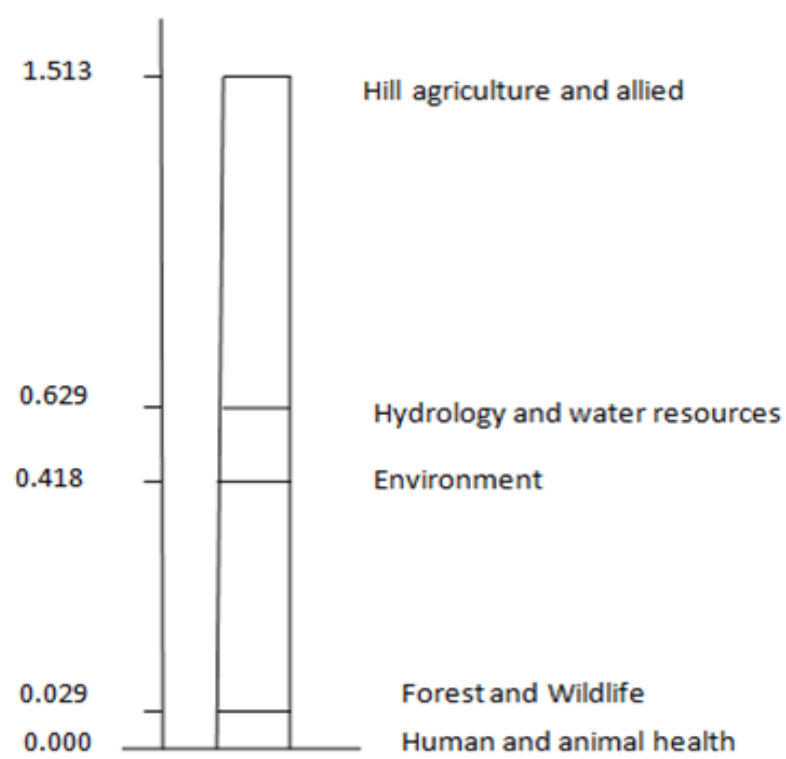

Fig. 1. Bar diagram showing hierarchy of the five components relating to climate change.

The next component which will be affected by climate change is Environment (A) having a scale value of $(0.418)$ and ranked $3^{\text {rd }}$. Rising temperatures and shifting precipitation patterns due to climate change also have an impact on the environment where animals, birds, insects, and plants thrives by affecting the timing of lifecycle events, such as bud bursts, leaf drop from trees, pollination, reproduction, bird migration and also helps in the growth of noxious weeds which competes with crops for nutrition uptake thereby reducing the yield. But according to the perception of scientists of CRRI (Cuttack), environment will be affected most severely due to climate change and it has been ranked $1^{\text {st }}$ (Mondal and Thokchom, 2014). These differences of perception between the scientists of CRRI, Cuttack and scientists of KVK of North-East are due to geographical and agro-climatic variations.

The next component which will be affected by climate change is Forest and wild life (D) having a scale value of $(0.029)$ and ranked $4^{\text {th }}$. Many tree species are adapted to particular temperature and moisture conditions. As these conditions change, habitats become unsuitable for saplings to grow, and animal, birds and insect species attempt to migrate. Because trees are so long-lived, the effects may not be noticeable for many years. However, species of birds, animals and plants that grows only in certain areas are slowly diminishing due to unfavourable climatic condition caused by global warming and climate change. Rising temperature also contributes to forest wild fire which causes a lot of destruction to both plants and animal at large.

The last component taking the $5^{\text {th }}$ ranked which will be least affected by climate change is Human and animal health (C) having a scale value of (0.00). The scale value (0.00) does not indicate absence of variables. The component "Human and animal health" had got some scale value. But its scale value had been brought down to arbitrary zero according to rules of interval scale. As the climate changes, the risk of injury, illness, and death from the resulting heat waves, wildfires, intense storms, and floods rise. Climate change greatly influences some of the most deadly and widespread diseases affecting people across the world. Insect vectors such as mosquitoes which is able to multiply in stagnating waters in tanks, and sewers and even a small rise in temperature favours its reproduction, thereby facilitating the spread of diseases like Malaria and Dengue fever (Sumana et al, 2006). Climate change also hase an impact on animal health whereby causing spread of waterborne and airborne pathogen which can survive and thrive more in rising temperature.

\section{Conclusion}

The findings revealed that Hill agriculture will be most adversely affected due to climate change in Meghalaya followed by hydrology and water resource, environment, forest and wild life ; and human and animal health. One of the main reason is practising of jhum cultivation. So, the scientists and the government of Meghalaya may adopt some necessary steps for controlling jhum cultivation and emphasis should be given on orchard and plantation crops instead of jhumming and should adopt necessary measures to mitigate the adverse effect of climate change on agriculture and human and animal health.

\section{REFERENCES}

Deepika, A. Pasricha, J.S. (2010). Climate change and its impacts on Indian agriculture. International journal of climate change:Impacts and Responses.2(3):163-172.

Edward, A.L. (1969). Techniques of attitude scale construction, Vakils, Feffer and Simonds Pvt. Ltd. Mumbai.

Mondal, S. (2013). Textbook of Agricultural Extension with Global Innovations.Kalyani ,Publishers,Ludhiana.

Mondal, S. and Thokchom, R. (2014). Impact of climate change as perceived by scientists of CRRI, Cuttack, Odisha. International Journal of Extension Education. 10:52-55.

Ramakrishnan, P.S. (1990). Agricultural systems of the North-eastern hill region of India. Agroecology Researching the ecological basis for sustainable agriculture.251-291.

Sasmita, M. and Mohanty, B.P. (2009). Global climate change:a cause of concern. National Academy Science Letters.32(5):149-156

Sumana, B., Sharma, C., Dhiman, R.C., and Mitra, A.P. (2006). Climate change and malaria in India. Current Science.90(3):369-375. 